\title{
Education Quality Improvement Through Usaid Prioritas Development (Multi-Case Study in State Elementary School Babatan I And State Elementary School Wiyung Surabaya
}

\author{
Nurul Faizah ${ }^{1, a}$, Bambang Suratman ${ }^{1, b}, \&$ Murtadlo $0^{1, c}$ \\ ${ }^{1}$ Department of Education Management, Postgraduate Program of State University of Surabaya, Indonesia \\ a nurulfaizah10@mhs.unesa.ac.id b Prof.Dr.Bambang.Suratman@unesa.ac.id, c Prof.Dr.Murtadlo @unesa.ac.id \\ ${ }^{*}$ Corresponding Author \\ Phone: 081330982226
}

How to Cite: Faizah, N., Suratman, B., Murtadlo. (2020). Education Quality Improvement Through USAID Prioritas Development (Multi-Case Study in State Elementary School Babatan I And State Elementary School Wiyung Surabaya. International Journal for Educational and Vocational Studies, 2(2), 169-173. DOI:

https://doi.org/10.29103/ijevs.v2i2.2283

\section{ARTICLE HISTORY}

Received:14 December 2019

Revised: 28 January 2020

Accepted: 6 February 2020

\section{KEYWORDS}

The quality of education; USAID Prioritas Development; School Management Development;

\section{ABSTRACT}

This study uses qualitative research, with the type of multi-case study research. The main data source in this study was obtained by snowball sampling. Data collection techniques in this study used three techniques, namely observation, interviews, and documentation. The locations used as research sites were State Elementary School Babatan I and State Elementary School Wiyung, which are partnering with USAID Prioritas. State Elementary School Babatan I before partnering with USAID was accredited B, but after partnering with USAID accredited A in 2016. State Elementary School Wiyung was able to maintain its accreditation after partnering with USAID. The conclusion of this study states that improving the quality of education in State Elementary School Babatan I and State Elementary School Wiyung has been reached. This can be seen from the acceleration of changes in both physical development, and human resources, especially teachers and students both in quantity and quality.

This is an open access article under the CC-BY-SA license

\section{INTRODUCTION}

The quality of education is the key word for increasing human resources. Development in the education field carried out by the government together with the community is to educate the nation's life. The process of national intelligence is an effort to embody one of the national ideals and this is done both through the school track and outside the school track. Educational institutions must position themselves as centers of excellence in the empowerment of the Indonesian nation's human resources. Therefore, the quality of national education needs to be improved and implemented as an integral part of the national development program.

To achieve Indonesian people who are expected to be in accordance with the objectives of national education as stipulated in the National Education System Law No. 20 of 2003 (Article 3), quality education is needed. The government has the obligation to provide equal rights for every citizen to obtain quality education. To guarantee this quality, the government needs to guarantee that each education unit has reached 8 (eight) education standards.
Education is a classic problems faced by the Indonesian nation where the quality of education at every level and unit of education, especially primary and secondary education, has not been able to show maximum results. There are three main factors causing the low quality of the learning process in Indonesia. The first is low quality assurance of education services. Up to 2013 , $68.7 \%$ of elementary school/ islamic elementary school and $62.5 \%$ of junior high school/ Islamic junior high school were accredited $B$. This shows that the quality of basic education services is still low, while on the other hand the quality of secondary education services is not evenly distributed between high school and vocational high school. At present $73.5 \%$ of senior high school/ Islamic senior high school are accredited B while only $48.2 \%$ of vocational high school competency skills are accredited B. The main cause of the low quality of primary and secondary education services is related to the school's limited understanding of the obligation to meet National Education Standards. In addition, the improvement of the quality of education services has not been designed based on the educational quality assurance process, so that the 
quality of learning is often not on target and not in accordance with school needs.

The second is the weak implementation of the curriculum. The 2013 curriculum implementation, which was quite massive in 2014 alongside the 2006 curriculum, caused several problems. The 2013 curriculum is considered not to have been sufficiently reviewed and not to have undergone sufficient trials to be applied in such a massive way by some. Problems are increasing because of limited teaching material and the low understanding of educators, principals, and parents. Therefore, a comprehensive evaluation of the 2013 Curriculum needs to be carried out.

The third is the weakness of the educational assessment system. A comprehensive and reliable educational assessment system has not yet been fully developed. This can be seen in part from the absence of: (i) the reliability and validity of the national examination system; (ii) minimal efforts to strengthen independent educational assessment institutions; (iii) no review of the role, structure and resources of the education assessment center; (iv) the results of monitoring student learning outcomes not having been utilized as information on continuously improving the quality of learning; and (v) the limited ability of educators to provide formative assessment. (Source: Strategic Planning of Education and Culture Ministry 2015-2019: 2015)

To realize quality school education, the principal is required to have a good and appropriate school education strategy or policy to overcome the obstacles that exist in efforts to improve the quality of school education as one source of reference in the professional development of educational staff (especially teachers). It is important that schools build partnerships with several education consultants in Indonesia, one of which is USAID. USAID in the initial observation study expressed support for Indonesia to improve education in Indonesia. Through USAID partners, it is hoped that schools can improve the quality of their education.

From preliminary observations at the study sites in State Elementary School Babatan I and State Elementary School Wiyung, it was found that State Elementary School Babatan I before partnering with USAID was accredited B, but after partnering with USAID accredited A in 2016. State Elementary School Wiyung was able to maintain its accreditation after partnering with USAID. Through this study, the researchers wants to analyze the improvement in the quality of education in State Elementary School Babatan I and State Elementary School Wiyung.

\section{MATERIALS AND METHODS}

Research on improving the quality of education in State Elementary School Wiyung and State Elementary School Babatan I through USAID partners used a qualitative approach with a multi-case study. Qualitative research is research that aims to analyze, understand and express phenomena, events, activities, social, attitudes, and perceptions of thought individually or in groups. The purpose of using qualitative research is to describe, uncover, and explain. Consequently, the results of this study are analyzing the improvement of the quality of education in State Elementary School Wiyung and State Elementary School Babatan I through USAID partners.

This study used qualitative methods that focus on multi-case studies. According to Baxter and Jack (2008) in a multi-case study, researchers examine several cases to understand the similarities and differences between the cases studied. The equation is the status of the schools is equal from the state, while the difference is the accreditation of State Elementary School Babatan I, first before partnering with USAID, was B; the accreditation after partnering with USAID was A, while State Elementary School Wiyung before partnering with USAID was accredited A; after partnering with USAID was accredited (A fat). It means that the increase in education at both schools is equally increasing.

Research subjects are people used as sources of information to uncover facts in the field (Arikunto, 2006: 145). Determination of research subjects or samples in qualitative research is chosen to obtain maximum information not based on statistical calculations. The data sources in this study were divided into two, namely: 1) the main data source was obtained in the form of words or verbally and the behavior of the subject (informant) and 2) the secondary data source was obtained from photographs, documents and objects used as a complement to the main data source (Arikunto, 2010: 130). The main data source in this study was obtained by snowball sampling to select and took samples through the process of rolling from one respondent to another respondent, while secondary data sources were in the form of documents, such as books, articles, scientific journals, letters or archives in State Elementary School Babatan I and State Elementary School Wiyung. Data collection techniques in this study used three techniques, namely observation, interviews, and documentation (Bogdan and Biklen, 2003: 38).

\section{RESULTS AND DISCUSSIONS}

State Elementary School Babatan I and State Elementary School Wiyung Surabaya are schools partnering with Usaid with different backgrounds, namely State Elementary School Babatan I, first before partnering with USAID, was B; the accreditation after partnering with USAID was A, while State Elementary School Wiyung before partnering with USAID had accredited A; after partnering with USAID had accredited (A fat). It means that the increase in education at both schools is equally increasing.

A. Education Quality Improvement in State Elementary School Babatan I and State Elementary School Wiyung Surabaya through USAID Partners 
The improving of the quality of education in terms of visionary school principal leadership is in consistent with the RPS and RKS. This is consistent with Daming's statement in Zazin (2011: 54); that is, quality means a solution to achieve continuous improvement. In the world of education, according to Daming, what can be applied in the world of education are (1) school board members and administrators must set educational goals; (2) emphasizing the failure attempts on students; (3) using statistical control methods to help improve student outcomes and administration. Something qualified is part of a very high standard that cannot be surpassed. A qualified product is something that is made perfectly and at a high cost. The product can be valued and makes the owner satisfied and proud.

Improving teachers' quality and professionalism ongoing basis has been covered by the KKG program. Even though at the beginning of its implementation, it was still not in line with the objectives of the USAID partners, the teachers began to be skilled at assisting peers; thus, it encourages the promotion of sustainable professional abilities. This is in accordance with the theory of Walker (2005) where lesson study is an assessment of the learning process in the real class conducted by a group of teachers in collaboration for a long time and continuously to improve their professionalism.

Arcaro quoted by Zahroh in the book Total Quality Management (2014: 28), Quality is a structured process to improve the output produced. The quality of education which is meant here is the ability of educational institutions in utilizing educational resources to improve learning abilities as optimal as possible. The impact on student learning outcomes after attending USAID has increased in terms of USBN scores and Outcomes generated by almost $90 \%$ of admission to the State. State Elementary School Babatan I and State Elementary School Wiyung were used as role models for schools in Surabaya, the role model based on adiwiyata for State Elementary School Babatan I and the literacy-based school role model for State Elementary School Wiyung.

B. Fostering school management through USAID PRIORITAS partners in State Elementary School Babatan I and State Elementary School Wiyung Surabaya.

Daming in Zazin (2011: 54), quality means a solution to achieve continuous improvement. In the world of education, according to Daming, what can be applied in the world of education are (1) school board members and administrators must set educational goals; (2) emphasizing the failure attempts on students; (3) using statistical control methods to help improve student outcomes and administration. Participatory school planning can be seen from the vision and mission of State Elementary School Babatan I and State Elementary School Wiyung. Furthermore, the principal must have an orientation to improve school quality that is compatible with the implementation of the quality of the principal's leadership. This is in accordance with the statement of Juran, Quality is defined as user suitability or appropriate for use. The approach is an orientation towards meeting customer needs, with several views; (1) achieving quality is an endless process; (2) quality improvement is a continuous process; (3) quality requires leadership from school board and administrative members; (4) quality prerequisite is the training of all school residents (Zazin, 2011: 55).

School management at State Elementary School Babatan I and State Elementary School Wiyung after partnering with USAID became participatory, accountable, transparent, and focused on improving the quality of learning. This is in accordance with the statement of Usman (2013) in his book Management: Theory of Practice and Educational Research, saying that quality has 13 Characteristics as follows: (a) Performance (performance): basic work characteristics, (b) Timeliness: completed with reasonable time, (c) Reliable (reliability): the length of work time, (d) Durability (durability): the length of time before the time of replacement or repair, (e) Beautiful (aesthethis): characteristics relating to the five senses, (f) Human interface (personal interface): human relations, (g) Easy to use (easy of use): free from the difficulties of use, (h) Special form (features): special features, (i) certain standards (conformance to specifcation): the degree to which a product design and the work characteristics of the product conform to specified standards, (j) Consistency: all the time, the same, and remain constant, (k) Uniform (uniformity): identical, without variation, ( l) Able to serve (serviceability ): problem solving and complaint handling. (m) Accuracy: the degree to which a quantity or statement is correct.

C. Fostering teachers through USAID PRIORITAS partners in State Elementary School Babatan I and State Elementary School Wiyung Surabaya.

USAID training uses an active and interactive learning approach. As a follow-up training for school principals, teachers, staff and school committees will be accompanied by facilitators to find out the level of success of USAID training. Assistance procedure by making an agreement with the school related to the right time of assistance, so that both parties are not disturbed by each other.

Sergiovani (1987: 68) defines coaching as a conscious effort to stimulate, coordinate and guide continuously the growth of teachers in schools both individually and in groups to better understand and be effective in realizing all learning functions.

In addition to facilitating training, the facilitator needs to provide assistance to the teacher as a follow-up activity to the training. The facilitator needs to accompany the teacher to be able to "ground" what has been learned during the training into real learning in class. Beside to the facilitator, the principal also monitors 
the learning process of the teacher in the classroom. In its implementation at school, the teacher is not only equipped with textbooks when he will enter the classroom but must try how the lesson plans that have been prepared can be implemented in achieving the learning objectives to the fullest. In line with the statement of Bafadal (2004: 44) where "Guidance based on its objectives is broadly grouped into two types of coaching, namely coaching abilities and fostering commitment".

D. The guidance and learning process of the USAID PRIORITAS version at State Elementary School Babatan I and State Elementary School Wiyung Surabaya.

The aim of improving the professionalism of educators in outlines covers two areas namely: school management and improving the quality of learning. The design of the training uses the lesson study model. This is in line with the objective of fostering professional competence to improve the professional abilities of teachers in improving the process and learning outcomes through the provision of assistance that is primarily patterned professional services to teachers (Imron, 1995: 12). With the guidance of USAID, it is hoped that it can improve the work effectiveness of a teacher in achieving work outcomes that have been determined for the teaching and learning process to run well, so that the teacher can become a professional in carrying out his duties.

The learning strategy used by USAID is to use training methods using an active and interactive learning approach. Teacher training materials vary according to the module prepared. The mentoring model uses the lesson study model. Assistance procedure by making an agreement with the school, related to the right time of mentoring, so that both parties are not disturbed by each other. The constraints in the implementation of coaching and the learning process are commitment and dissemination. This is consistent with the integrated approach undertaken by USAID PRIORITAS aimed at improving the quality of education in Indonesia. One of the strategies used in achieving improvement in the quality of education is by linking governance, science and technology, innovation, and the involvement of the private sector with development goals in the field of education. An integrated approach will have a greater impact than combining the parts. One key aspect of the integrated approach is the involvement of the community, non-governmental organization (NGO), and local media to encourage better State services and the provision of technical assistance to the government in increasing its capacity to meet the needs of the community in the education field.

\section{CONCLUSION}

The conclusion of this study states that improving the quality of education through USAID partners in State Elementary School Babatan I and State Elementary School Wiyung has been reached (1) the results of the study indicate that teacher professional improvement has been accommodated through the KKG, the impact of student learning outcomes is increasing seen from the USBN scores and student outcomes almost 90\% enter the country. State Elementary School Babatan I and State Elementary School Wiyung became role models for schools in Surabaya. The role model based on adiwiyata for State Elementary School Babatan I and the literacy-based school role model for State Elementary School Wiyung. Objectives (2) the principal's leadership has experienced a visionary improvement seen from several changes in the vision and mission of the school to become a quality school and school management to be participatory, accountable, transparent, and focused on improving the quality of learning. Objectives (3) USAID training uses an active and interactive learning approach. As a follow-up training for school principals, teachers, staff and school committees will be accompanied by facilitators to find out the level of success of USAID training. Assistance procedure by making an agreement with the school, related to the right time of mentoring makes both parties not disturbed by each other. Objectives (4) The USAID learning process is organized according to modules prepared with the aim to improve the professionalism of educators in broad outline covering two areas namely: school management and improving the quality of learning. The design of the training uses the lesson study model.

\section{REFERENCES}

Amri, Sofan. (2013). Pengembangan \& Model Pembelajaran Dalam Kurikulum 2013. Jakarta: Prestasi Pustakarya

Arikunto, S. (2010). Prosedur penelitian : Suatu Pendekatan Praktik. (Edisi Revisi). Jakarta : Rineka Cipta.

Bafadal, Ibrahim. (2004). Manajemen peningkatan Mutu Sekolah Dasar. Jakarta: Bumi Aksara.

Best, John W dan Kahn, James, V. (1989). Research in Education. New Delhi: Prentice-Hall of India

Bogdan, Robert C. dan Biklen Kopp Sari, (1982), Qualitative Research for Education: An Introduction to Theory and Methods. Allyn and Bacon, Inc.: Boston London.

Departemen Pendidikan Nasional, (2003). Undang-Undang Nomor 20 Tahun 2003, Tentang Sistem Pendidikan Nasional. Jakarta: Depdiknas.

Evans, J.R, and Lindsay, W.M. (2005). The Management and Control of Quality, Sixth Edition. Singapore: Thomson South Western.

Fattah, Nanang. (2013). Landasan Manajemen Pendidikan. Bandung: Remaja Rosdakarya.

Gaspersz, Vincent. (2002). Pedoman Implementasi Program Six SigmaTerintegrasi dengan ISO 9001: 2000 MBNQA dan HCCP. Jakarta : PT Gramedia Pustaka Utama

Hamalik, Oemar. (2005). Kurikulum dan Pembelajaran. Jakarta: Bumi Aksara.

Imron, Ali. (1995). Pembinaan Guru di Indonesia. Jakarta: Pustaka Jaya.

Juran, J. M. Gryna, Frank, M dan Bingham, R. S. (1980). Quality Control Handbook (third edition). New York: Mc. 
Graw Hill.

Miles, M.B, Huberman, A.M. (1994). Qualitative data analysis, 2nd ed. USA: Sage Publication..

Mulyasa, E. (2007). Menjadi Guru Profesional menciptakan Pembelajaran Kreatif dan Menyenangkan. Bandung : Rosdakarya.

Riyanto, Yatim. (2007). Metodologi Penelitian Pendidikan Kualitatif dan Kuantitatif. Unesa University Press.

Roesminingsih, MV. Susarno, Lamijan H. (2012). Teori dan Praktek Pendidikan. Lembaga pengkajian dan pengembangan ilmu pendidikan FIP UNESA.

Sallis, Edward. (2011). Total Quality Management in Education (Diterjemahan oleh Riyadi, Ahmad Ali \& Fahrurrozi). Jogjakarta: IRCiSoD.

Sergiovanni, Thomas J.et.al. (1987). Educational Governance and Administration. New Jersey: Prentice Hall Inc.

Sugiyono. (2009). Metode Penelitian Bisnis (Pendekatan Kuantitatif, Kualitatif, dan R\&D). Bandung: Alfabeta.

Syaodih, Nana. (2006). Pengendalian Mutu Pendidikan Sekolah Menengah (Konsep, Prinsip, dan Instrumen). Bandung: PT.Refika Aditama.

Usman, Husaini. (2013). Manajemen (Teori, Praktik dan Riset Pendidikan). Jakarta: Bumi Aksara.

Zazin, Nur. (2011). Gerakan Menata Mutu Pendidikan: Teori \& Aplikasi. Yogyakarta: Ar-Ruzz Media. 